\title{
Communication Strategy for Breastfeeding Mothers in Stunting Prevention in Banyumas
}

\author{
Prita Suci Nurcandrani ${ }^{1, a)}$ Sefy Andhriany 2) \\ 1,2 Univeritas Amikom Purwokerto, Indonesia \\ a) author correspondence: prita.suci@amikompurwokerto.ac.id
}

DOI: https://doi.org/10.18196/jkm.122044

Article Info

Article history: Received 03Feb 2018 Revised 20Feb 2018 Accepted 26 Feb 2018

\section{ABSTRACT}

Stunting could have a major bad impact on the quality of Indonesia's human resources in the future, and startlingly in the North Purwokerto Sub-district, Banyumas Regency, it reached 261 cases in 2019. This study aimed to analyze the communication strategy carried out by the Kasih Jeruk Purut Program on breastfeeding mothers as an effort to prevent stunting in that sub-district. This study used qualitative research methods, and data were drawn by observation, in-depth interviews, and review of documentation. The results showed that this phenomenon was caused by a lack of support from the family, minimum crosssectoral integrity cooperation, and limited understanding of breastfeeding mothers regarding the concept of breastfeeding management. There was also identified that some of the cadres did not fully understand the concept of effective communication.

Keywords: Breastfeeding; Effective Communication; Health Communication Strategy; Stunting

\section{ABSTRAK}

Stunting dapat berdampak sangat buruk terhadap kualitas sumber daya manusia Indonesia di masa depan, dan yang mengejutkan di Kecamatan Purwokerto Utara, Kabupaten Banyumas mencapai 261 kasus pada tahun 2019. Penelitian ini bertujuan untuk menganalisis strategi komunikasi yang dilakukan oleh Program Kasih Jeruk Purut terhadap ibu menyusui sebagai salah satu upaya pencegahan stunting di kecamatan tersebut. Penelitian ini menggunakan metode kualitatif, dan pengambilan data dilakukan dengan observasi, wawancara mendalam, dan telaah dokumentasi. Hasil penelitian menunjukkan bahwa fenomena tersebut disebabkan oleh kurangnya dukungan dari keluarga, minimnya kerjasama integritas lintas sektoral, dan masih terbatasnya pemahaman ibu menyusui tentang konsep manajemen menyusui. Teridentifikasi pula bahwa sebagian kader belum sepenuhnya memahami konsep komunikasi efektif.

Keywords: ASI; Komunikasi Efektif; Strategi Komunikasi Kesehatan; Stunting 


\section{INTRODUCTION}

Banyumas Regency constitutes one of the top hundred regions with the highest stunting rate in Indonesia. The stunting rate in Banyumas reaches 24 percent from a sample size of 300 toddlers, while the WHO standard is a maximum of 20 percent. The Banyumas Regency Health Office concluded that stunting cases in the North Purwokerto Sub-district area in 2019 were quite high, reaching 261 cases compared to South Purwokerto with 17 cases (Head of Planning Sub Division of Banyumas Regency Health Office).

Stunting or stunted or so-called short is a condition of failure to thrive in children aged under five years (toddlers). A child is classified as stunted if the length or height is below minus two of standard deviations of a child's length or height in his/her age (Pusat Data dan Informasi, 2018). The National Strategy for the Acceleration of Prevention of Stunting for the 2018-2024 Period is a reference for all parties, from central, regional, to village levels. In this national strategy, three main priorities are formulated, namely priority targets, priority locations, and priority interventions. The priority targets in accelerating the prevention of stunting are pregnant women, breastfeeding mothers, and children aged 0-23 months considered as the first 1,000 days of life. These households are the main focus of all interventions to accelerate stunting prevention.

The government has determined that stunting prevention should be accelerated in all regencies /cities. In 2018, one hundred priority regencies/cities were decided, and in 2019 it increased to 160 priority regencies/cities. The government has also identified 260 districts/cities, which will be priority locations for stunting prevention by 2020 . This number will continue to increase gradually to cover 514 regencies/cities in Indonesia until 2024. The third priority, namely priority interventions, covers the various main interventions needed to accelerate the prevention of stunting, including specific nutrition interventions or sensitive nutrition interventions (TNP2K, 2019).

Table 1. Specific Nutrition Interventions

\begin{tabular}{|c|c|c|c|}
\hline Target Group & Priority Interventions & $\begin{array}{c}\text { Supporting } \\
\text { Interventions }\end{array}$ & $\begin{array}{c}\text { Priority Interventions } \\
\text { According to Conditions }\end{array}$ \\
\hline $\begin{array}{l}\text { Pregnant } \\
\text { mother }\end{array}$ & $\begin{array}{l}\text { Providing additional } \\
\text { food for pregnant } \\
\text { women with chronic } \\
\text { energy deficiency } \\
\text { Provision of } \\
\text { supplementation with } \\
\text { blood added tablets }\end{array}$ & $\begin{array}{ll}\text { - } & \text { Giving calcium } \\
\text { supplementation } \\
\text { - } \\
\text { Pregnancy } \\
\text { examination }\end{array}$ & $\begin{array}{lll}\text { - } & \begin{array}{l}\text { Protection } \\
\text { malaria }\end{array} \\
\text { - } & \text { HIV prevention } & \end{array}$ \\
\hline $\begin{array}{l}\text { Breastfeeding } \\
\text { mothers and } \\
\text { children aged } \\
0-23 \text { months }\end{array}$ & 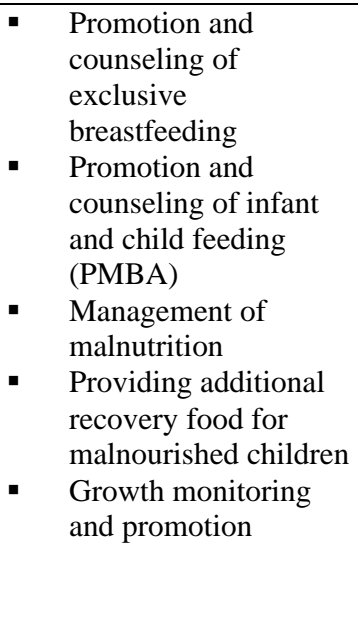 & 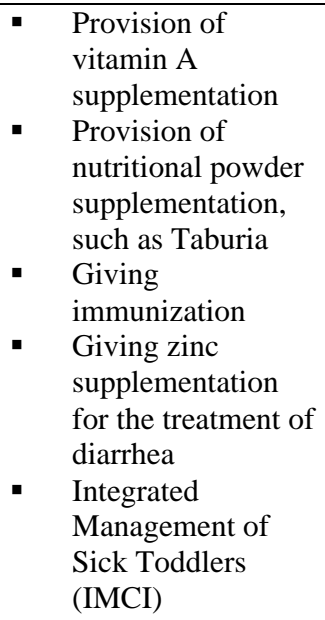 & \\
\hline
\end{tabular}

Source: National Strategy for the Acceleration of Stunting Prevention 2018-2024

Stunting has a major impact on the quality of Indonesia's human resources in the future. Stunted children tend to have lower cognitive abilities than normal children. When growing up, their productivity is, on average, 20 percent lower. In addition, stunted children are susceptible to degenerative non-communicable diseases. Stunting is caused by chronic malnutrition and recurrent infections, especially during the first 1,000 days of life (HPK), that is, from fetuses to children aged 
23 months. Therefore, one of the priority targets of the National Strategy for the Acceleration of Prevention of Stunting 2018-2024 is breastfeeding mothers and children aged 0-23 months, where the priority intervention is promotion and counseling on exclusive breastfeeding.

The Banyumas Regent is highly committed to preventing stunting. At least there are regional regulations and Regent decrees issued regarding the prevention of stunting, including Local Regulation No. 41/2014 on Maternal Health, Newborns, Babies and Toddlers (KIBBLA), Local Regulation No. 25/2015 concerning exclusive breastfeeding, and decrees of Regent Number 440/638 of 2018 concerning the formation of a Special Team for the prevention and handling of stunting.

The Community Health Centre (Puskesmas) II of North Purwokerto supports priority interventions carried out by the Banyumas Regent by forming breastfeeding support groups in its working area. The program created is an innovation program called Kasih Jeruk Purut or the Great Breastfeeding Cadre Network for Health in North Purwokerto. The program, which was formed at the end of 2018, originated with the problem of exclusive breastfeeding coverage, which only reached $76 \%$, while the target was above $90 \%$. Based on these data, the Kasih Jeruk Purut Program aims to increase the coverage of exclusive breastfeeding in the work area of Puskesmas II of North Purwokerto, which main objective is to reduce infant and under-five mortality and prevent stunting. The target area of this innovation program includes four urban villages, namely Grendeng, Sumampir, Karangwangkal, and Pabuaran, with a total of 131 breastfeeding mothers (Puskesmas II Purwokerto Utara, 2019).

Table 2. Data of Infants aged 0-6 months

\begin{tabular}{clc}
\hline No & \multicolumn{1}{c}{ Village (Kelurahan) } & Number of Babies \\
\hline 1 & Sumampir & 35 \\
2 & Grendeng & 54 \\
3 & Karangwangkal & 29 \\
4 & Pabuwaran & 13 \\
\hline & TOTAL & 131 babies \\
\hline
\end{tabular}

Source: Puskesmas II Purwokerto Utara Primary data: processed (2019)

The Head of the Kasih Jeruk Purut Program said that her team had difficulties in how to provide education about exclusive breastfeeding to breastfeeding mothers. As a result, breast milk coverage has not been fully completed. Based on the background of the problem, this research is to analyze the communication strategy carried out by Kasih Jeruk Purut on breastfeeding mothers as an effort to prevent stunting in Banyumas Regency.

The previous studies related to exclusive breastfeeding education to breastfeeding mothers that have been conducted among others are. A study revealed that the effectiveness of breastfeeding techniques is closely related to higher educational status. In addition, there is a need for immediate counseling after the birth process and at least two visits to communities with lower educational levels. Health care providers should organize education about the effectiveness of breastfeeding techniques and ensure postnatal care, especially primiparous (women who deliver their babies for the first time).(Tiruye \& Mesfin, 2018)

An examination of maternal behavior related to exclusive breastfeeding had been conducted in Ghana. The findings of the study identified that health care providers are key figures in information and education programs regarding exclusive breastfeeding for breastfeeding mothers. Social and religious influences also play a significant role in shaping breastfeeding behavior, especially perceptions of exclusive breastfeeding. Factors that allow this behavior to influence include the support of husbands, families, and the social environment. The driving force for the success of exclusive breastfeeding for six months is self-motivation and education about exclusive breastfeeding, despite the inconvenience and short time off. For the success of the exclusive breastfeeding program, policies that promote exclusive breastfeeding, facilities, and support for breastfeeding mothers are needed (Boateng, 2018).

Meanwhile, an article discussed risk factors associated with underweight children, stunting, and infants aged 0-24 months who were malnourished in six districts in the Kilimanjaro region. A total of 1,870 children were involved in the study, and it can be seen that the prevalence of malnutrition in the six areas is quite high namely $41.9 \%$ stunted growth. In the study, the level of maternal education was linked to communication strategies with underweight, stunted children, and infants (Mgongo, 2017). 
A research article analyzed the effect of nutritional intake, history of infectious diseases, environmental sanitation, and immunization status on the incidence of stunting. The results of this study indicated that nutritional intake and history of infectious diseases have a positive influence on the incidence of stunting. Meanwhile, immunization status has no direct effect on the incidence of stunting (Yustisia, Yales., 2019).

In the meantime, a study uncovered that around $29 \%$ of children under five years are in the category of dwarf. The study was conducted in the working area of Puskesmas I Tegallalang and took five samples of mothers having stunted children identified some phenomena. Some respondents conveyed that they provided exclusive breastfeeding to their children up to six months but on an irregular basis. Most respondents started providing complimentary breastfeeding or additional foods since the baby was in six months old. However, respondents ignored nutritional needs, frequency of feeding, types of good foods, and the right variety of foods. These findings also disclosed that the wrong pattern of feeding caused stunting in children. Therefore, it is necessary to pay more attention to this problem to reduce the stunting rate.(Pradnyawati, Luh Gede, Kartinawati, Komang Triyani \& Juwita, 2019)

A scrutiny showed that stunting and even severe stunting cases are caused by several factors. At the individual level, the preventive efforts to reduce the incidence of stunting are to focus on improving the women's nutrition to abate baby with low birth weight, improving household hygiene to decrease the incidence of diarrhea, and promoting more varied supplementary feeding. At the community level, the intervention was for uneducated mothers with low social status. The emphasis which has no less important, namely mothers living in the northern region of Nigeria, and the intervention strategy will be improved in Nigeria with a nutritional improvement target set by WHO to cut down stunting by $40 \%$ of children under five years old by 2025 (Akombi, B.J., Agho, K.E, Hall, J.J., Merom, Dafna, Burt, Thomas Astell, Renzaho, n.d.).

An inquiry assessed the factors playing an essential role in the stunting case in children under five years of age (Pusat Data dan Informasi Kesehatan, 2018). The results proved that stunting has a significant relationship with several factors. The breastfeeding period over 12 months is closely related to low-income family economic status and has a high potential for stunting. Children living together with low-income family status are more prone to stunting than others. This study described in more detail the quantity, the quality, and practice of supplementary feeding. Further, it is necessary to have an inter-sectoral policy regarding adequate nutrition that emphasize households with low socioeconomic conditions that had the potential of stunting.

A research aimed to analyze the factors causing stunting in children aged 2-3 years identified some results that stunting is not directly affected by the length of birth of the baby, the weight of the baby, birth, exclusive breastfeeding and supplementary feeding time. However, stunting is indirectly influenced by family income, maternal age, behavior, mother's height, occupation, education and maternal knowledge (Barir, Baroroh, Murti, Bhisma, Pamungkasari, 2019).

A study analyzed the relationship between duration or time of breastfeeding and malnutrition in children up to age 3 years. The results of this research indicated the breastfeeding in the second and third years of early life of infants has a relationship with stunting and even severe stunting. Mothers need to be illuminated about the risks of lengthy breastfeeding to decrease malnutirion cases in Pakistan.(Syeda, Batool, Agho, Kingsley, Wilson, 2020)

An inquiry about exclusive and non exclusive breastfeeding among stunted and normal children in Indonesia identified some results. Among others, although the incidence of stunting is more common in groups of mothers who do not provide exclusive breastfeeding, however, there is no significant difference in the proportion of children aged 6-9 months between both the groups. However, exclusive beastfeeding should still be encouraged. (Rusmil, Viramitha Kusnandi, Prahastuti, Tri Oktaviani, Luftimas, Dimas Erlangga, Hafsah, 2019)

Based on the results of research mentioned above, it can be concluded that the communication strategy carried out by health service providers is influenced by several factors. Mothers with higher educational backgrounds are more receptive to information conveyed by health service providers and therefore, do not require more effort to formulate a communication strategy. Consciously, these mothers are more active in seeking information about exclusive breastfeeding. Support from various parties such as husband, family and social environment also influences the communication strategy of health service providers to formulate health. Meanwhile, stunting itself has a very close relationship with malnutrition and lack of breastfeeding in the first and second year of life of infants. 
A communication theory that is often used in the realm of health communication stating that communication will be effective if it can change a person's attitude. This goal will be achieved if the communicator has three communication competencies namely, knowledge of what is being informed, communication skills, and communication motivation (Stephen Littlejohn, n.d. 2017).

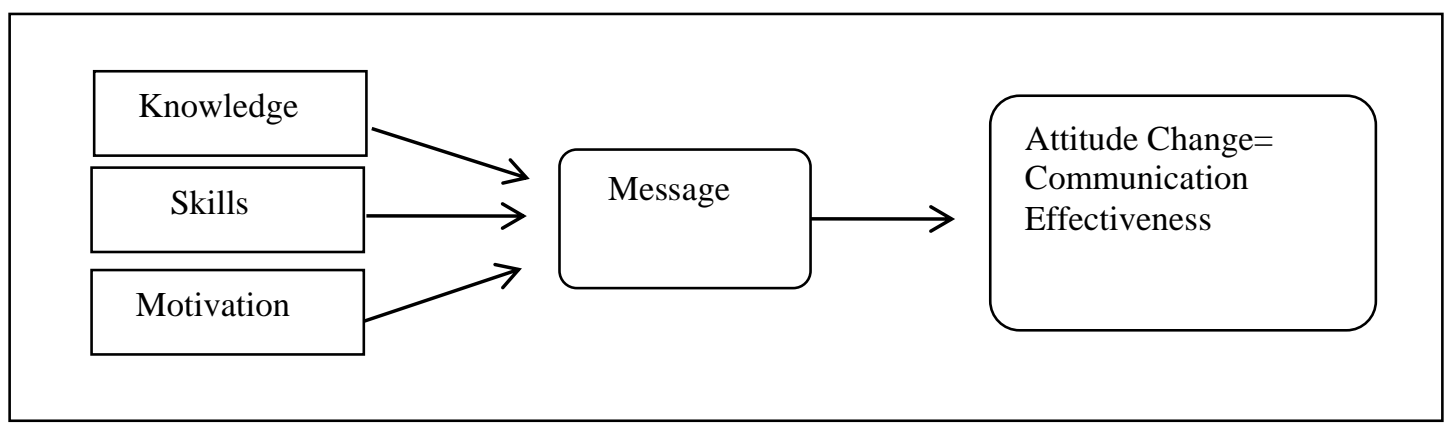

Figure 1. Communication Competency Theory (Stephen Littlejohn, n.d.2017)

Some of the knowledge includes knowing what to say, what kind of behavior to take in various situations, and how other people will respond and behave. In addition, knowledge of who is invited to communicate and understanding the contents of the message conveyed must be taken into account as well. The quality and quantity of knowledge will continue to increase in line with higher education and more experience. Thus, the more a person knows how to communicate in different situations, the better his/her competency or ability to communicate.

Motivation is usually associated with a specific set of goals, such as forging new relationships, getting the desired information, and being involved in joint decision making. The more individuals have the desire to communicate effectively and leave a good impression on others, the higher their individual's motivation to communicate. In this case, the responses given by others will affect the individuals' desire to communicate. If the individual is too afraid to get unwanted responses, then his desire to communicate will be low.

Skills include concrete actions of behavior, which is a person's ability to process the behavior needed to communicate appropriately and effectively. This capability includes several factors, such as other-orientation, social anxiety, expressiveness, and interaction management. Otherorientation includes behavior that shows individuals are interested in and caring for others. In this case, individuals are able to hear, see, and feel what other people say both verbally and nonverbally. Other-orientation will be opposite to self-centeredness, where individuals only pay attention to themselves and are less interested in communicating with others. Social anxiety includes how the individual's ability to overcome anxiety in talking with others and show calm and confidence in communicating. Expressiveness refers to the ability to communicate which shows joy, enthusiasm, and intensity, and variability in communication behavior. The ability to communicate can be seen from the use of various vocals, expressive faces, extensive use of vocabulary, and gestures. Meanwhile, interaction management is the ability to manage interactions in communication.

A communication strategy is a way of managing the execution of a communication operation to be successful. Communication strategy is essentially planning and management to achieve one goal. To achieve this goal, a strategy does not only function as a road map that only shows directions but must also show operational tactics (Zainal, 2015).

In order to accelerate stunting prevention, a strategic situation analysis is needed to describe the direct and indirect causes of stunting in each region for the preparation of intervention programs that will be carried out. Situation analysis can be done by studying primary and secondary data, survey/study results, media news, case reports, interviews with various stakeholders related to stunting, journals, and other related information. This is done to identify gaps and determine strategic options in developing a communication strategy.

The communication strategy approach formulated by the Ministry of Health of the Republic of Indonesia in 2018 includes public campaigns, policy advocacy, social mobilization, social change communication, and behavior change communication. This approach is targeted at the parties concerned. In this case, more emphasis is placed on the primary target group consisting of 
breastfeeding mothers so that it will discuss more about behavior change communication. The description of the behavior change approach includes strategic use of individual and interpersonal communication to promote the expected output of stunting prevention behavior, working through interpersonal communication and supported by mass media/social media campaigns. The communication strategy is structured based on theory and research, as well as the target group interaction process in order to form key messages and the most suitable communication approach to motivate individual knowledge, attitudes, and behavior consistently and sustainably In connection with the communication function as a means of persuasion, communication skills can be used as a tool to persuade or direct others (Maulana \& Gumelar, 2013). Communication through language and signs has the power to influence and invite others to follow ideas, invitations, and behavior models displayed by the communicator. Communication as a persuasive tool is a very important function in interpersonal relationships. Efforts to make other people obey or follow what the communicator wants are the most common and used communication goals (Morissan, 2010).

This study aimed to analyze the communication strategy carried out by Kasih Jeruk Purut Program as an effort to prevent stunting in the sense of increasing the coverage of exclusive breastfeeding in the working area of Puskesmas II of North Purwokerto.

\section{METHODS}

This study used qualitative research methods. Data collection was carried out through observation, in-depth interviews, and review of documentation. The primary data in this study were in the form of words and actions of three groups of people observed or interviewed. Firstly, mothers with babies of 0-6 months consisting of 16 people spreading on 4 villages in the Puskesmas II of North Purwokerto work area. Secondly, cadres of Kasih Jeruk Purut consist of 12 breastfeeding mothers. Thirdly, two officers of Puskesmas II of North Purwokerto consisting of a counselor and head of the Puskesmas were considered to be able to help obtain research data. This study used triangulation of sources in which the research explored the truth of information through methods and sources of data collection. Primary data sources are recorded through written notes, recordings, and photographs. Secondary data used in this study were written sources in the form of documents, files, or archives from the Banyumas Regency Health Office and Puskesmas II of North Purwokerto. In addition, a study of references in the form of books and articles in journals relevant to the research was conducted as well.

\section{RESULT AND DISCUSSION}

Lactation counseling was carried out by lactation counselors at Puskesmas II of North Purwokerto, who had attended breastfeeding counseling training for 40 hours of lessons with the WHO modifier. Lactation counseling was held in the nutrition counseling room of Puskesmas II of North Purwokerto, home visits to clients' homes, or conducted simultaneously with weighing babies and toddlers at the Integrated Service Post (Posyandu).

Lactation counseling activities were only carried out if a breastfeeding mother has a breastfeeding problem. Interventions must be made to identify the cause of the problem of breastfeeding and to solve the problem so that breastfeeding could run normally and comfortably. Data regarding counseling activities are shown in the table below:

Table 3. Lactation Counseling Patients from 2018-2020

\begin{tabular}{|c|c|c|c|c|c|}
\hline No. & $\begin{array}{c}\text { Patient's } \\
\text { name }\end{array}$ & $\begin{array}{l}\text { Medical } \\
\text { record }\end{array}$ & Visiting time & Origin & Problem \\
\hline 1 & EAZ & 31492 & $12-3-2019$ & Sumampir & Relactation \\
\hline 2 & AZA & 30822 & $30-1-2019$ & Grendeng & Relactation \\
\hline 3 & MYS & 0028346 & $27-8-2018$ & Purwosari & $\begin{array}{l}\text { BB does not rise and the } \\
\text { attachment position is } \\
\text { uncomfortable }\end{array}$ \\
\hline 4 & AN & 27864 & $17-7-2018$ & Sumampir & Relactation \\
\hline 5 & BAP & 32382 & $11-5-2019$ & Karangwangkal & Mother feels a little milk \\
\hline 6 & $\mathrm{FE}$ & 33916 & $16-9-2019$ & Grendeng & Baby confused nipples \\
\hline 7 & SAP & 32426 & $2-10-2019$ & Pabuwaran & $\begin{array}{l}\text { Towards complementary } \\
\text { foods }\end{array}$ \\
\hline
\end{tabular}


In this counseling activity, patients conveyed that the counselor was able to explain and demonstrate how to provide proper breastfeeding and good attachment. This was stated by the nursing mother WY (Pabuwaran): "The explanation given was good and clear. The counselor was quite capable of answering my questions." The nursing mother NY (Sumampir) added: "At the beginning of breastfeeding, I often felt anxious and hopeless because my child didn't want to, even cried all the time. Maybe I didn't know how to breastfeed properly. But the counselor continued to encourage and give directions, so that I was more patient and willing to teach until the baby is willing to breastfeed." In this case, (Corey, 2015) stated that the quality of the relationship between counselor and counselee seems to be the most likely to create relationship growth between the two. Thus, counseling involves a professional relationship that provides assistance and is very dependent on the counselor's personality qualities. The quality and quantity of the counselor's knowledge will continue to increase along with the higher education and the amount of experience (Stephen Littlejohn, n.d. 2017).

Furthermore, a counselor must also be able to master several competencies including knowing what to say, what kind of behavior to take in various situations, and how other people will respond and behave. In addition, knowledge of who is invited to communicate, as well as understanding the contents of the message conveyed, should be considered. Thus, the more a person knows how to communicate in different situations, the better his/her competence or ability to communicate (Stephen Littlejohn, n.d. 2017).

As can be seen in Figure 2, the counselor came to the patient's house/home visit because the patient was not allowed to come to the Posyandu or Puskesmas. The patient had twins in which the patient was worried and desperate about how the patient would be able to breastfeed properly, and the anxiety increased whether the breastmilk was sufficient for the two babies. NY (Sumampir) nursing mother stated that the counselor was willing to listen and was very empathetic with the difficulties she was facing. It seems that counselors emphasize other-orientation where individuals are able to hear, see and feel what other people convey both verbally and nonverbally.

In her article also emphasized that effective communication does not take too long. Effective communication has been shown to take less time because counselors are skilled at recognizing patient needs. In providing medical services, the existence of effective communication between counselors and counselees is an expected condition so that counselors can manage health problems with the counselee based on patient needs (Liansyah, 2015).

In line with NY (Sumampir) breastfeeding mothers, PA breastfeeding mothers (Grendeng) stated that the counselor always gave encouragement at the end of the counseling. "The counselor seemed to really know my condition, she always gave me motivation, so that I would continue to breastfeed for at least the next six months." One of the things that is quite important in counseling is the skill to end counseling by providing reinforcement in the form of both verbal and gesture (Capuzzi, D Gross, 2013).

\section{Education}

Counseling was carried out in an integrated manner with pregnant women class activities in four urban villages, namely Sumampir, Grendeng, Karangwangkal, and Pabuwaran. Counseling was carried out to increase the knowledge of pregnant women about the benefits of Early Breastfeeding Initiation (IMD), exclusive breastfeeding 0-6 months, nutrition for pregnant women. Meanwhile, the class for pregnant women is conducted every month with 15 participants per village with midwives, nutritionists, and health promoters, general practitioners, and dentists. Classes for pregnant women were held from February to November 2019 in four villages within the North Purwokerto Puskesmas Sub-district working area, namely Sumampir, Grendeng, Karangwangkal, and Pabuwaran.

Extension of infant and child feeding (PMBA) was run in February and November 2019. The targets of the extension were mothers of toddlers, and the locations for counseling were at the Puskesmas and Posyandu. The counseling was conducted to increase the knowledge of mothers with under five infants and of child feeding (PMBA) according to WHO standards. 
This is in line with the results of research, which showed that there are differences in the knowledge of breastfeeding mothers regarding correct breastfeeding techniques before and after counseling. Mother's knowledge increased significantly after being given counseling, and she was motivated to practice the material delivered by the officer on her own. (Faridah, 2017)

\section{Breastfeeding Motivator Training}

Based on the preliminary survey conducted on breastfeeding cadres in the work area of Puskesmas II of North Purwokerto, it is known that there are factors causing mothers to be unable to breastfeed exclusively, including a lack of awareness and knowledge of the benefits of exclusive breastfeeding, a lack of confidence in mothers that they are able to breastfeed their babies exclusively, and do not understand the concept of pumping milk management when the leave period is over. RE (Initiator of the Kasih Jeruk Purut Program) said: "Breastfeeding mothers in our area are not even able to provide exclusive breastfeeding to babies aged 0-6 months because they have to work. In addition, breastfeeding mothers feel that they or their breast milk is not sufficient for the baby's nutrition, so they give formula milk to the baby, which is considered to fulfill the baby's nutrition.

Training activities for breastfeeding cadres were held in December 2019 as a form of refreshing and updating the latest knowledge on breastfeeding and exclusive breastfeeding. This training was attended by 35 breastfeeding cadres from 4 urban villages, namely Sumampir, Grendeng, Karangwangkal, and Pabuwaran. The materials provided included the benefits of exclusive breastfeeding, breastfeeding position, and attachment, BMI, risks of formula milk, management of breast milk, and good practice of attachment position for breastfeeding.

The aim of this training is to provide knowledge to breastfeeding cadres to help early detect problems of breastfeeding mothers encountered in their area. In addition, cadres are expected to be able to provide practical assistance to breastfeeding mothers, such as providing examples of good position and attachment when practicing breastfeeding. If a problem that needs to be assisted by a lactation counselor appears, the breastfeeding cadre can refer them to the Puskesmas to get lactation counseling services according to the problem.

\section{The Use of Media}

The media used in the counseling activities included baby dolls, breast models, leaflets, booklets, brochures and flipcharts containing feeding of babies and children accompanied by counseling cards for cadres. Apart from using the media, the counselor also provided assistance and demonstrations during the breastfeeding process. Other assistive devices were also used, such as glass bottles for pumping the breastmilk, pipettes, and small cups for the medium of giving breast milk.

Meanwhile, at the time of counseling, the media that was more frequently used were Power Point materials regarding exclusive breastfeeding, IMD, and feeding for babies and children. If necessary and possible, the practice of making MP ASI also required original food ingredients and eating equipment to measure portions of complementary foods according to WHO standards.

In line with the results of this study, in their research stated that the use of pocketbook media is also very helpful. They are coupled with with the use of simulation methods, making it easier for mothers to understand the material presented. The use of these two methods has been shown to increase the knowledge of breastfeeding mothers because they can stimulate the enthusiasm of mothers in learning material about exclusive breastfeeding (Merdhika, W.A.R., Mardji, M. \& Devi, 2014).

\section{Integrated Antenatal Care (ACT)}

This ACT activity is an integrated activity where pregnant women receive nutritional counseling services regarding balanced nutritional intake and for breastfeeding preparation. This activity aims to change the behavior of pregnant women so that later when they enter the breastfeeding phase, they can provide exclusive breastfeeding for 0-6 months for their babies, it is stated that adequate that adequate ACT services are proven not only to reduce morbidity and mortality of mothers, fetuses and babies, but also to improve health status and parenting behavior of mothers after the child is born (Dalle et al. 2015). 


\section{CONCLUSION}

Exclusive breastfeeding coverage in the work area of Puskesmas II of North Purwokerto only reached $76.07 \%$ in October 2019. This figure is still quite far from the target set by the Indonesian Ministry of Health, which is $90 \%$. This is due to a lack of support from the family, a lack of crosssectoral integrity cooperation, and a lack of understanding of breastfeeding mothers regarding the concept of management of breastmilk. So, when they finish their leave, the mother no longer gives exclusive breastfeeding to her baby. On average, mothers who have finished their leave replace them with formula milk because they are worried that breast milk is not sufficient for the baby's needs.

In addition, there are still some cadres who do not understand the concept of effective communication. As a result, information about exclusive breastfeeding has not been conveyed properly to mothers. In fact, breastfeeding cadres have been provided with comprehensive knowledge and information from health workers at Puskesmas II of North Purwokerto but the delivery to breastfeeding mothers is still not good.

Communication strategies carried out by Puskesmas II of North Purwokerto include counseling, elucidation, and use of media. The ACT socialization is accomplished before the mother gives birth. This is intended to do in order that at post-partum, physically and psychologically mothers are able to give exclusive breastfeeding more comfortably and optimally.

Given that there are still limitations and shortcomings in this innovation program, and based on the results of monitoring and evaluation, it is necessary to plan follow-up steps, including:

Increasing the latest information and knowledge for Health Workers and Excellent Breastfeeding cadres related to the Kasih Jeruk Purut Innovation activity, it can be done by conducting training on effective communication for cadres of Excellent Breastfeeding Health Network for North Purwokerto (Kasih Jeruk Purut) by collaborating with the Communication Studies Program of AMIKOM University, Purwokerto.

Getting support in increasing the coverage of exclusive breastfeeding within the work area of Puskesmas II of North Purwokerto, establishing Cross-sectoral cooperation is recommended. Also, using above line media such as radio and community television to carry out social marketing for exclusive breastfeeding for 0-6 months by means of an MOU with the Communication Studies Program of AMIKOM University, Purwokerto.

Providing lactation rooms in agencies or offices is one of the ways to increase the coverage of exclusive breastfeeding for working mothers. The other way is delivering advocacy to agencies existing in the working area of Puskesmas II of North Purwokerto, such as sub-districts, villages (kelurahan), schools, public spaces, and restaurants to provide lactation rooms or nursing rooms.

Strengthening the referral system in lactation counseling, cooperating with existing social organizations such as the Indonesian Breastfeeding Mother Association (AIMI) Purwokerto Branch can be accomplished. Further, promoting the Integrated AntiNatal Care (ACT) Program in order that the prevention of stunting can be started when the baby is still in the womb.

A joint commitment is needed to support the success of giving exclusive breastfeeding to infants aged 0-6 months in the work area of Puskesmas II of North Purwokerto. The coverage of exclusive breastfeeding can increase and prevent infant and under-fives mortality and prevent stunting in underfives.

\section{Acknowledgment}

We, the researchers, hereby express our gratitude to Puskesmas Purwokerto Utara II and Universitas Amikom Purwokerto for supporting the implementation of this research.

\section{REFERENCES}

Abidin, Yusuf Zainal. (2015). Manajemen Komunikasi (Filosofi, Konsep dan Aplikasi). Bandung: Pustaka Setia.

Akombi, B.J., Agho, K.E, Hall, J.J., Merom, Dafna, Burt, Thomas Astell, Renzaho, Andre M.N., (2017). Stunting and Severe Stunting among Children Under-5 Years in Nigeria: A Multilevel Analysis. BMC Pediatric. 17:15. https://doi.org/10.1186/s12887-016-0770-Z 
Ambarwati, R., Siti Fatimah Muis \& Purwanti Susantini. (2013). Pengaruh konseling laktasi intensif terhadap pemberian air susu ibu (ASI) eksklusif sampai 3 bulan. Jurnal Gizi Indonesia, 2(1), 15-23.

Barir, Baroroh, Murti, Bhisma, Pamungkasari, Eti Poncorini. (2019). The Association between Exclusive Breastfeeding, Complementary Feeding, and The Risk of Stunting in Children Under Five Years of Age: A Path Analysis Evidence from Jombang East Java. Journal of Maternal and Child Health, 4(6), 486-498. https://doi.org/10.26911/thejmch.2019.04.06.09

Boateng, Mavis F. (2018). Knowledge, Attitude and Practice of Exclusive Breastfeeding among Mothers in Techiman, Ghana. Thesis.

Capuzzi, D., \& Gross, D. R. (2013). Introduction to The Counseling Profession. UK: Routledge.

Cetthakrikul, N., Topothai, C., Suphanchaimat, R. (2018). Childhood Stunting in Thailand; When Prolonged Breastfeeding interacts with Household Poverty. BMC Pediatric, 18:395. https://doi.org/10.1186/s12887-018-1375-5

Corey, G. (2015). Theory and Practice of Counseling and Psychotherapy. Canada: Nelson Education.

Faridah, S. (2017). Perbedaan Pengetahuan Tehnik Menyusui Sebelum dan Sesudah Penyuluhan. Indonesian Journal for Health Sciences, 1(1), 17-22.

Galle A, Van Parys A, Roelens K, Keygnaert. (2015). Expectations and satisfaction with antenatal care among pregnant women with a focus on vulnerable groups: a descriptive study in Ghent. United Kingdom: BMC Women's Health.

Getahun Tiruye, Firehiwot Mesfin, Biftu Geda \& Kasiye Shiferaw. (2018).Breastfeeding technique and associated factors among breastfeeding mothers in Harar city, Eastern Ethiopia. International Breastfeeding Journal, 13:5.

Kemenkes RI. (2013). Riset Kesehatan Dasar; RISKESDAS. Jakarta: Balitbang Kemenkes RI.

Liansyah, Tita Menawati dan Hendra Kurniawan. (2015). Pentingnya Komunikasi dalam Pelayanan Kesehatan Primer. Jurnal Kedokteran Syiah Kuala, 15(2).

Littlejohn, Stephen. (2017). Theories of Human Communication. USA: Wadsworth Publishing.

Maulana, H., \& Gumelar, G. (2013). Psikologi Komunikasi dan Persuasi. Jakarta: Akademia Pratama.

Merdhika, W.A.R., Mardji, M. \& Devi, M., (2014). Pengaruh Penyuluhan ASI Eksklusif terhadap Pengetahuan Ibu tentang ASI Eksklusif dan Sikap Ibu Menyusui di Kecamatan Kanigoro Kabupaten Blitar. Teknologi Kejuruan: Jurnal Teknologi, Kejuruan, dan Pengajarannya, 37(1), 65-72. http://dx.doi.org/10.17977/tk.v37il.4108

Mgongo, Melina. (2017). Underweight, Stunting and Wasting among Children in Kilimanjaro Region, Tanzania; a Population-Based Cross-Sectional Study. International Journal of Environtmental Research and Public Health, 14(5).

Moleong, Lexy J. (2017). Metodologi Penelitian Kualitatif. Bandung: Remaja Rosdakarya Offset.

Morissan, M. A. (2010). Psikologi Komunikasi. Bogor: Ghalia Indonesia.

Notoatmodjo, S. (2014). Ilmu Perilaku Kesehatan. Jakarta: Rineka Cipta.

Pradnyawati, Luh Gede, Kartinawati, Komang Triyani \& Juwita, Dewa Ayu Putu Ratna. (2019). Parenting Pattern of Feeding in Stunting Toddlers at The Working Area of Tegallalang I Primary Health Centre. Journal of Community Empowerment for Health, 2(2), 208216.https://doi.org/10.22146/jcoemph.47019

Pusat Data dan Informasi Kesehatan. (2018). Buletin Jendela Data dan Informasi Kesehatan. Jakarta: Kementerian Kesehatan

Rusmil, Viramitha Kusnandi, Prahastuti, Tri Oktaviani, Luftimas, Dimas Erlangga, Hafsah, Tisnasari. (2019). Exclusive and Non Exclusive Breastfeeding among Stunted and Normal 6-9 MonthOld-Children in Jatinangor Subdistrict Indonesia. Althea Medical Journal, 6(1) 35-41. https://doi.org/10.15850/amj.v6n1.1598

Syeda, Batool, Agho, Kingsley, Wilson, Leigh. (2020). Relationship between Breastfeeding Duration and Undernutrition Conditions among Children Aged 0-3 Years. International Journal of Pediatrics and Adolescent Medicine. https://doi.org/10.1016/j.ijpam.2020.01.006

TNP2K. (2019). Pengembangan Peta Status Gizi Balita di Indonesia. Jakarta: Kementerian Kesehatan.

Yustisia, Yales.,Riana Anmaru \& Budi Laksono.(2019).The Influencing Factor Analysis of Stunting Incidence in Children Aged 24-59 Months At Kedung Jati Village. Public Health Perspectives Journal, 4(2), 116 - 121. 